\title{
PENGARUH DIKLAT TERHADAP KINERJA GURU MADRASAH DI KOTA MANADO
}

\section{THE EFFECT OF IN SERVICE TRAINING ON THE PERFORMANCE OF MADRASAH TEACHERS IN MANADO CITY}

\author{
Muhammad Rais \\ Balai Penelitian dan Pengembangan Agama Makassar \\ Jl. AP. Pettarani No. 72 Makassar \\ Email: raispuslit2@gmail.com
}

Naskah diterima tanggal 2 Februari 2019, Naskah direvisi tanggal 19 Maret 2019, Naskah disetujui tanggal 30 Mei 2019

\begin{abstract}
Abstrak
Artikel ini bertujuan untuk mengukur dan sekaligus mendeskripsikan secara kuantitatif dikombinasikan kualitatif, pengaruh diklat terhadap kinerja guru di Madrasah yang telah mengikuti diklat mata pelajaran pada Balai Diklat Keagamaan Manado, tahun 2016-2017. Dengan memanfaatkan metode kombinasi dalam mengumpulkan data: kuantitatif dan kualitatif. Ditinjau dari respons guru dengan menggunakan pengukuran skala Likert terhadap dimensi materi diklat dengan tujuan indikator, rerata direspons dengan kategori baik, dimensi kualitas widyaiswara rata-rata direspons dengan kategori baik, dimensi metode diklat rerata direspons dengan kategori baik. Adapun tingkat respons terhadap variabel Y (kinerja guru), yang di-breakdown dari empat kompetensi dengan masing-masing indikatornya, sebagai berikut: 1) kompetensi pedagogis; 2) kompetensi kepribadian; 3) kompetensi profesional, dan 4) kompetensi sosial. Keempat kompetensi tersebut rata-rata direspons dengan kategori baik. Adapun tingkat pengaruh diklat terhadap kinerja guru, dapat dilihat pada hasil analisis regresi diperoleh koefisien regresi yang mengindikasikan bahwa, faktor (variabel) metode diklat, materi diklat, dan kompetensi widyaiswara berpengaruh terhadap kinerja guru madrasah, meskipun belum signifikan. Sementara sisanya, dijelaskan oleh faktor-faktor lainnya yang tidak menjadi bagian penelitian ini; selain metode, materi dan widyaiswara.
\end{abstract}

Kata kunci: pengaruh, pendidikan dan latihan, kinerja, guru, madrasah

\begin{abstract}
This article aims to measure and simultaneously describe quantitively and qualitatively, the influence of education and training on the performance of teachers in Madrasas who have participated in subject training in the Manado of Religious Education and Training Center, 2016-2017. By utilizing combination methods: quantitative and qualitative. Judging from the teacher's response using the Likert Scale measurement of the dimensions of training material with the aim of indicators, the average is responded to in a good category, the dimensions of the quality of instructors / facilitators on average are responded to in a good category; the dimensions of the quality of instructors / facilitators on average are responded to in good categories; the dimensions of the average training method were responded to in a good category. The level of response to variable $Y$ (teacher performance), breakdown of four competencies with each indicator, as follows: 1) pedagogic competence; 2) personality competence; 3) professional competence; 4) social competence. The four competencies on average were responded to in good categories. The level of influence of education and training on teacher performance can be seen in the results of the regression analysis, regression coefficients that indicate that, the factors (variables) of training methods, training materials, and widyaiswara competencies influence the performance of madrasa teachers, although not yet significant. The rest is explained by other factors besides methods, material and instructors / facilitators.
\end{abstract}

Keywords: influence, in service training, performance, teacher, madrasah 


\section{PENDAHULUAN}

$\mathrm{D}$ iklat merupakan salah satu elemen penting dalam kerangka pengembangan sumber daya manusia di setiap organisasi. Sehingga, tepat kiranya jika muncul klaim bahwa, Pendidikan dan Latihan (diklat) Aparatur Sipil Negara (ASN), tak terkecuali pendidik sebagai penentu di garda terdepan ketercapaian tujuan pendidikan, menjadi sangat strategis posisinya. Pengembangan kapasitas sumber daya manusia penyelenggara diklat, baik pada domain materi, metode, dan kapasitas widyaiswara sebagai upaya peningkatan kualitas dan kapasitas. Termasuk, pemenuhan kebutuhan riil di lingkungan Kementerian Agama dalam upaya peningkatan kualitas pelayanan, khususnya pada kementerian tersebut.

Berkenaan dengan peran strategis balai diklat keagamaan, terdapat beberapa regulasi yang secara spesifik mengafirmasi, diantaranya Pasal 1 Ayat (11) Peraturan Menteri Agama Nomor 4 tahun 2013 bahwa, Balai Diklat Keagamaan adalah unit pelaksana Teknis di lingkungan Badan Penelitian dan Pengembangan serta Pendidikan dan Pelatihan Kementerian Agama, Pasal 2 bahwa, tujuan dilakukannya Pendidikan dan Pelatihan oleh Balai Diklat adalah untuk meningkatkan kompetensi teknis PNS dan Pegawai non-PNS yang meliputi pengetahuan, keahlian, keterampilan, sikap dan perilaku agar sesuai dengan standar kompetensi teknis yang dibutuhkan oleh satuan organisasi dan/atau jabatannya.

Mengacu pada deskripsi di atas, yang mengindikasikan masih adanya gap (kesenjangan) antara apa yang seharusnya, dalam hal ini kapasitas serta kualitas guru sebagaimana yang diamanahkan dalam regulasi maupun yang semestinya dipenuhi guru, dengan realitas faktual yang tampak kini (senyatanya), maka pertanyaan penelitian yang sejatinya dijawab melalui penelitian ini adalah: Bagaimana performa Balai Diklat Keagamaan Kota Manado, serta sejauh mana Pengaruh Diklat Mata Pelajaran terhadap peningkatan kinerja guru madrasah di Kota Manado?
Penelitian ini bertujuan untuk mengukur secara kuantitatif pengaruh diklat terhadap kinerja, sekaligus mendeskripsikan-dengan metode kualitatif-performa penyelenggaraan diklat guru yang selama dua tahun terakhir, yang berjalan di beberapa diklat keagamaan, serta pengaruh penyelenggaraan pendidikan dan pelatihan guru mata pelajaran tersebut, terhadap capaian kinerja mereka di madrasah yang ada di Kawasan Timur Indonesia, dilihat dari sisi konteks, input, proses dan produk (outcome), termasuk layanan yang sejatinya menjadi kewajiban balai-balai diklat tersebut, meliputi: materi diklat, metode diklat, dan ketersediaan pelatih (trainer) yang kompeten.

Penelitian ini diharapkan secara langsung maupun implementatif bagi kalangan stakeholders, dapat digunakan sebagai basis pengambilan kebijakan, dalam upaya optimalisasi tata kelola penyelenggaraan pendidikan dan pelatihan bagi kalangan guru mata pelajaran di madrasah, baik diklat yang selenggarakan di lingkungan Pusdiklat Tenaga Teknis maupun di balai-balai diklat keagamaan di Kawasan Timur Indonesia.

\section{Tinjauan Pustaka \\ Pendidikan dan Pelatihan}

Pelatihan bagi kalangan guru sangat urgen, sebagaimana yang dikemukakan Sutermeister (dalam Musfah, 2015: 210) bahwa, kemampuan dihasilkan dari pengetahuan serta keterampilan. Pengetahuan dipengaruhi oleh Pendidikan, pengalaman, pelatihan, dan juga minat. Keterampilan dipengaruhi oleh bakat dan kepribadian, sebagaimana juga oleh Pendidikan, pengalaman, pelatihan, dan minat. Selaras dengan itu, Bradley dalam tulisannya "Developing School: Making Inset Effective School," mengemukakan terkait pentingnya pelatihan bagi guru, sehingga mereka dapat mengajarkan hal-hal baru bagi para siswanya, dan sekolah mampu menghadapi setiap perubahan dengan penuh percaya diri. Sehingga, setelah melalui proses diklat, guru mampu meningkatkan efektivitas pembelajaran, menaikkan prestasi belajar siswa, dan menyebabkan guru memiliki keinginan yang lebih kuat untuk menerima berbagai inovasi baru. 
Dengan demikian, menurut Hammond, et.al (2005),"The Design of Teacher Education Programs," bahwa, "pelatihan sejatinya mengarusutamakan kebutuhan riil guru, berkenaan dengan fungsinya sebagai pengajar dan pendidik, tidak semata memberikan pengetahuan teoritis”. Jejen Musfah (2015: 211) menemukan beberapa penyebab belum efektifnya diklat guru selama ini, diantaranya, Pertama, berkenaan dengan materi dan metode penyampaian, pelatihan lebih sarat dengan pembelajaran teoritis-konseptual. Namun, faktanya, pelatih lebih memilih metode ceramah daripada metode-metode pembelajaran aktif, Kedua, masalah seputar peserta, kerap kali peserta yang dikirim sekolah/madrasah tidak sesuai dengan kualifikasi akademik yang diminta panitia, misalnya diklat untuk guru matematika, tetapi yang dikirim malah guru Bahasa Inggris. Ketiga, masalah waktu, waktu diklat sangat sempit, sehingga materi pelatihan tidak dipahami secara utuh oleh guru. Keempat, pelatih yang tidak kompeten, diklat guru sudah menjadi proyek yang dimanfaatkan untuk kepentingan kelompok tertentu, sehingga mengabaikan aspek kompetensi siapa melatih dan materi apa yang relevan. Maka, tak heran jika sampai beresonansi pada ketidaktercapaian tujuan diklat, karena pelatih bukan orang yang menguasai materi.

\section{Kinerja Guru}

Konsep kinerja yang merupakan singkatan dari kinetika energi kerja yang padanannya dalam Bahasa Inggris adalah performance. Dalam perbincangan sehari-hari kerap digunakan dalam Bahasa Indonesia performa (Wirawan, 2009:5). Dalam bentang nalar yang selaras, Moeheriono (2012: 68), mengartikulasikan konsep kinerja acapkali juga dimaknai sebagai penampilan, unjuk kerja, dan prestasi. Dalam Kamus Oxford Dictionary (2013), istilah tersebut menunjuk pada "the execution or fulfilment of a duty" (pelaksanaan/pencapaian atau pemenuhan suatu tugas). Kinerja juga kerap dimaknai, " a task or operation seen in terms of how successfully it is performed (suatu tugas dan pelaksanaan kerja yang tampak pada bagaimana pelaksanaannya hingga sukses).
Adapun indikator kinerja sebagaimana dirumuskan OECD-DAC (dalam Kusumastusi, 2014: 29) adalah faktor atau variabel kuantitatif maupun kuantitatif yang dapat memberikan cara yang sederhana serta andal untuk mengukur suatu capaian maupun hasil, ataupun sebagai refleksi perubahan yang dihasilkan dari suatu intervensi, dan juga dapat membantu untuk menilai kinerja suatu agen pembangunan.

Dengan demikian, meskipun penelitian ini tidak berpretensi untuk mematahkan temuantemuan sebelumnya. Tetapi, dengan memanfaatkan metode yang dikombinasikan antara kuantitatif dan kualitatif, diharapkan akan ditemukan kebaruan (novelty) dan nilai tambah (additional) pada kajian-kajian ilmiah sebelumnya. Selain memang, hasil penelitian ini tidak berhenti pada sebatas exercise academic, melainkan diorientasikan pada paradigma penelitian kebijakan-pendidikan-yang akan menghasilkan rekomendasi bagi pengambil kebijakan terkait tata kelola pendidikan, dan tak terkecuali tata kelola diklat maupun kinerja guru madrasah yang menjadi domain pembinaan Kementerian Agama RI. Maka, di titik inilah penelitian berkenaan dengan uji pengaruh diklat terhadap kinerja guru madrasah menjadi sangat penting dilakukan.

\section{Definisi Operasional Variabel}

Variabel dalam penelitian ini dikelompokkan menjadi variabel bebas dan variabel terikat. Variabel bebas adalah pendidikan dan pelatihan yang terdiri dari metode yang digunakan (X1), materi pendidikan dan latihan(X2) dan pelatih diklat (X3). Sedangkan variabel terikat adalah kinerja guru (Y). Definisi operasional masing-masing variabel adalah sebagai berikut:

Variabel bebas: Pendidikan dan pelatihan adalah suatu proses kegiatan pendidikan dan pelatihan bagi guru madrasah dalam rangka pengembangan sumber daya manusia seiring dengan tuntutan peningkatan mutu pendidikan, variabel tersebut adalah 1) X1: Metode pelatihan: adalah metode belajar mengajar yang digunakan dalam pemberian diklat kepada pegawai. Indikatornya adalah (a).metode yang digunakan dan (b) dukungan fasilitas dalam pelaksanaan metode; 2) X2: 
Materi diklat: persepsi responden tentang pemilihan materi dalam pelaksanaan diklat. Indikatornya adalah (a) kesesuaian materi diklat dan (b) kemanfaatan kegiatan diklat, dan 3) X3: Pelatih diklat: instruktur yang menyampaikan materi kepada peserta diklat. Indikatornya adalah (a) kemampuan pelatih, dan (b) kualitas pelatih. Adapun variabel terikat penelitian ini adalah kinerja, yang merupakan hasil kerja yang dicapai para guru madrasah dalam melaksanakan tugas yang dibebankan. Dimensi dan indikator penelitian sepenuhnya mengacu pada UU Nomor 14 tahun 2005 tentang Guru dan Dosen, yang mensyaratkan guru memiliki beberapa kompetensi, meliputi: (a).Kompetensi pedagogi, (b) kompetensi kepribadian, (c). Kompetensi profesional, (d) kompetensi sosial.

\section{Pengukuran Variabel}

Pengukuran variabel yang digunakan adalah dengan menggunakan Skala Likert, mengukur dengan cara menghadapkan seorang responden pada sebuah pertanyaan dan kemudian diminta untuk memberikan jawaban yang diberi skor 1 sampai 5, sebagai berikut:

$\begin{array}{ll}\text { - Sangat Baik } & \text { : skor 5 } \\ \text { - Baik } & : \text { skor 4 } \\ \text { - Tidak Tahu } & : \text { skor 3 } \\ \text { - Kurang Baik } & : \text { skor 2 } \\ \text { - Sangat tidak Baik } & \text { : skor 1 }\end{array}$

\section{Analisis Regresi Linier Berganda}

Analisis regresi digunakan menganalisis pengaruh variabel bebas terhadap variabel terikat. Model yang dipergunakan adalah regresi linier berganda (multiple linier regression) analisis regresi yang lazim digunakan untuk menganalisis data yang terdiri atas sejumlah peubah $\mathrm{X}$ dengan sebuah peubah $\mathrm{Y}$ dengan formula menurut Walpole dan Myers (dalam Furqon, 2009: 231) sebagai berikut:

$$
\mathbf{Y}=\mathbf{a}+\mathbf{b} 1 \mathbf{X} 1+\mathbf{b} 2 \mathbf{X} 2+\mathbf{b} 3 \mathbf{X} 3+\mathbf{e}
$$

Dimana:

$\mathrm{Y}=$ Kinerja guru

a $=$ Konstanta

b- $=$ Koefisien regresi

$\mathrm{X} 1$ = Metode yang digunakan

$\mathrm{X} 2$ = Materi pendidikan dan latihan

$\mathrm{X} 3$ = Pelatih $/$ instruktur diklat

$$
\mathrm{e} \quad=\text { variabel eror }
$$

\section{Uji Asumsi Multikolinieritas}

Multikolinieritas berarti adanya hubungan linier yang sangat kuat antar variabel bebas dalam regresi. Model regresi yang bagus mengasumsikan tidak adanya multikolinieritas atau tidak adanya hubungan yang sempurna antar variabel bebas yang satu dengan lainnya. Untuk mendeteksinya dilakukan dengan cara melihat nilai koefisien korelasi antar variabel bebas, yaitu dengan melihat nilai VIF (Variance Inflating Factor). Menurut Sumodiningrat (1999) bila nilai VIF lebih kecil dari 10 maka tidak terdapat gejala multikolinoeritas atau non multikolinieritas.

\section{Uji Asusmsi Heteroskedastisitas}

Heteroskedastisitas berarti variasi residual tidak sama untuk semua pengamatan, atau semakin besarnya residual untuk pengamatan yang semakin banyak. Model regresi yang baik adalah residual bersifat konstan atau sama untuk berbagai pengamatan. Gejala heteroskedastisitas diuji melalui chart scatterplot. Apabila titik-titik yang terdapat dalam charts tersebut membentuk pola titik-titik yang teratur seperti gelombang, melebar kemudian menyempit berarti terjadi heteroskedastisitas. Namun apabila terdapat pola yang tidak jelas atau acak, menyebar diatas dan dibawah angka 0 pada sumbu Y, maka tidak terjadi heteroskedastisitas.

\section{Uji Normalitas}

Uji normalitas bertujuan untuk menguji apakah dalam model regresi kedua variabel (bebas dan terikat) mempunyai distribusi normal atau tidak. Model regresi yang baik adalah model yang memiliki distribusi data normal atau mendekati normal. Pada prinsipnya normalitas dapat dideteksi dengan melihat penyebaran data (titik), pada sumbu diagonal pada grafik atau dengan melihat histogram dari residunya. Dasar pengambilan keputusan, yaitu: (1) Jika data menyebar di sekitar garis diagonal dan mengikuti arah garis diagonal atau garis histogramnya menunjukkan pola distribusi normal, maka model regresi memenuhi asumsi normalitas; (2) Jika data menyebar jauh dari 
garis diagonal dan tidak mengikuti garis diagonal atau grafik histogramnya tidak menunjukkan pola distribusi normal, maka model regresi tidak memenuhi asumsi normalitas.

\section{Pengujian Hipotesis}

Selanjutnya hasil analisis regresi linier berganda diuji dengan pengujian parsial, sehingga hasil temuannya memenuhi standar signifikansi yang baku.

Pengujian secara parsial dilakukan untuk mengetahui pengaruh masing-masing variabel bebas yaitu (X1) ,(X2) dan (X3) terhadap variabel terikat(Y). Untuk itu digunakan teknik "Uji t" dengan formula sebagai berikut:

$$
\mathbf{t}=\frac{\mathbf{b i}}{\text { Sbi }}
$$

Dimana:

bi $=$ Koefisien regresi

Sbi $=$ Standar eror koefisien regresi

Apabila nilai signifikansi t lebih kecil dari $5 \%$ atau $\mathrm{t}$ hitung $>\mathrm{t}$ tabel, maka dinyatakan signifikan yang berarti secara parsial variabel bebas berpengaruh terhadap variabel terikat. Dan sebaliknya bila signifikansi t lebih besar dari 5\%(0,05) atau t hitung $>\mathrm{t}$ tabel, maka secara parsial variabel bebas tidak berpengaruh terhadap variabel terikat. Pengujian hipotesis ini digunakan untuk menguji variabel-variabel bebas yang mempunyai pengaruh paling dominan terhadap variabel terikat.

Hipotesis statistik dinyatakan sebagai berikut :Ho : $\beta 1=\beta 2=\beta 3=0$, Hipotesis null (Ho) ini berarti bahwa variabel bebas tidak berpengaruh dominan terhadap variabel terikat. Ha: Minimal salah satu koefisien \# 0, Hipotesis alternatif (Ha) ini berarti bahwa salah satu variabel bebas berpengaruh dominan terhadap variabel terikat. Apabila di antara variabelvariabel bebas yang mempunyai nilai koefisien regresi (R) lebih besar di antara yang lainnya. Maka, variabel tersebut merupakan variabel yang paling dominan berpengaruh terhadap variabel terikat.

\section{METODE PENELITIAN}

method $\begin{gathered}\text { Penelitian ini memanfaatkan mixed } \\ \text { (kombinasi kuantitatif dengan }\end{gathered}$ kualitatif). John Creswell (2010: 5) mengartikulasikan mixed method sebagai pendekatan penelitian yang mengombinasikan atau mengasosiasikan bentuk kualitatif dan bentuk kuantitatif. Pendekatan ini akan menghasilkan data numerik dan data naratif untuk menjawab pertanyaan penelitian.

Teknik analisis korelasi product moment, dalam upaya melihat pengaruh variabel bebas atau variabel X (pendidikan dan pelatihan) terhadap variabel terikat (kinerja guru). Penelitian ini merupakan penelitian penjelasan (explanatory research) dengan menggunakan metode survei yaitu penelitian yang berusaha menjelaskan hubungan kausal antara variabelvariabel melalui pengujian hipotesis. Uji hipotesis dapat menjelaskan pengaruh antara variabel bebas dan variabel terikat, sekaligus deteksi pengaruh yang paling kuat antara variabel bebas tersebut. Dalam konteks penelitian ini populasi dan sampelnya terdiri dari Guru Madrasah Ibtidaiyyah, Tsanawiyah, dan Aliyah yang telah mengikuti Diklat Mata Pelajaran tahun 2016-2017 pada Wilayah Kerja Balai Diklat Keagamaan Kota Manado. Teknik pengambilan sampel menggunakan metode Proportional Random Sampling, jumlah sampel yang diambil dari populasi, ditentukan dengan menggunakan rumus Slovin (Sevilla, et.al, 1993: 161).

Guru madrasah yang telah mengikuti diklat mata pelajaran tahun 2016-2017 guru madrasah yang telah mengikuti diklat pada Balai Diklat Keagamaan Manado total 396 orang. Data-daya yang dibutuhkan dalam penelitian ini akan menggunakan instrumen kuesioner digunakan untuk menjaring data kuantitatif yang dikembangkan dimulai dengan telaah literatur mengenai variabel yang diteliti yang dikembangkan lebih jauh menjadi beberapa indikator. Sementara data kualitatif yang menurut Sharram B. Merriam, et.al (2016: 102) merupakan penuturan masyarakat, berkenaan dengan pengalaman, opini, perasaan dan pengetahuan yang mereka miliki, yang diperoleh melalui proses wawancara (direct quotations 
from people about their experiences, opinions, feelings, and knowledge's, obtained through interviews), dan juga observasi.

Teknik analisis data akan menggunakan analisis statistik inferensial yang berfungsi untuk menggeneralisasikan hasil penelitian ini dengan beberapa sampel terhadap populasi penelitian (seluruh guru madrasah yang mengikuti diklat tahun 2016-2017). Teknik korelasi product moment, digunakan dalam upaya melihat pengaruh variabel bebas atau variabel $X$ (pendidikan dan pelatihan) terhadap variabel terikat (kinerja guru). Adapun data kualitatif dianalisis berdasarkan teknik yang sudah lazim dilakukan dalam metode riset ini, meliputi: pengaturan data, pengkodean, kategorisasi dan interpretasi (Daymon, et.al, 2008: 368).

\section{PEMBAHASAN}

\section{Profil Balai Diklat Keagamaan Manado}

Diklat merupakan salah satu domain yang memiliki otoritas dalam pengembangan pegawai yang muaranya berimplikasi pada peningkatan kapasitas dan kualitas aparatur sipil negara. Mengingat posisi strategis diklat, maka Kementerian Agama sangat concern untuk mendorong kinerja Lembaga tersebut, salah satu bukti pemihakan tersebut ditandai dengan ditetapkannya Peraturan Menteri Agama Nomor 75 tahun 2015 tentang Penyelenggaraan Pendidikan dan pelatihan pegawai di lingkungan Kementerian Agama. Sebagai hasil revisi dan atau penyempurnaan regulasi sebelumnya; Peraturan Menteri Agama nomor 1 tahun 2003 tentang pedoman Pendidikan dan pelatihan Pegawai Negeri Sipil di lingkungan Departemen Agama jo Peraturan Menteri Agama Nomor 4 tahun 2012 tentang Penyelenggaraan Diklat teknis di lingkungan kementerian Agama.

\section{Balai Diklat Keagamaan Manado}

Wilayah kerja BDK Manado yang dibentuk pada tahun 1981 ini, terdiri dari Provinsi Sulawesi Tengah; Provinsi Gorontalo, dan Provinsi Maluku Utara, termasuk IAIN Manado, IAIN Gorontalo, IAIN Ternate, dan STAKN Manado dengan agregat aparatur sipil negara sebanyak 6.125 orang.

\begin{tabular}{|l|l|l|l|l|l|}
\hline \multicolumn{1}{|c|}{ Jabatan } & \multicolumn{5}{c|}{ Pendidikan } \\
\hline Pejabat Struktural & S1< & S1 & S2 & S3 & Jumlah \\
\hline Eselon III & & & 1 & & 1 \\
Eselon IV & - & - & 3 & - & 3 \\
Pejabat Fungsional & & & & & \\
(Widyaiswara) & - & 6 & 11 & 1 & 18 \\
Fungsional Umum & 4 & 14 & 6 & - & 24 \\
\hline
\end{tabular}

Berdasarkan tabel di atas terdeskripsi Sumber Daya Manusia BDK Manado yang sampai saat ini memiliki Aparatur Sipil Negara (ASN) agregat 47 orang (laki-laki 22 dan perempuan 24), termasuk tenaga honorer. ASN tersebut jika diklasifikasikan berdasarkan agama; Islam sebanyak 44 orang dan Kristen 3 orang. Golongan/pangkat ASN BDK Manado berada di interval IId-IV/b

Dari sisi tipologi diklat yang telah dilakukan keempat BDK di atas, dapat diklasifikasikan dalam tiga rumpun diklat sebagaimana yang diafirmasikan Badan Litbang dan Diklat Kementarian Agama RI, terdiri dari: 1) Rumpun diklat Tenaga Administrasi yang diklasifikasikan dalam empat jenis diklat, yakni diklat prajabatan; diklat fungsional administrasi; diklat teknis administrasi, dan diklat PIM IV. 2) Rumpun diklat tenaga teknis Pendidikan, meliputi diklat teknis fungsional Pendidikan; dan diklat teknis substantif Pendidikan; 3) rumpun diklat tenaga teknis keagamaan, meliputi diklat teknis fungsional keagamaan dan diklat teknis substantif keagamaan.

Terkait diklat guru yang diselenggarakan di BDK Manado dalam interval 2016-2017 yang menjadi fokus penelitian ini, terdiri dari: 1) diklat teknis substantif media pembelajaran berbasis multimedia guru madrasah (rumpun diklat teknis/substantif) dengan peserta 30 orang; 2) diklat peningkatan administrasi pembelajaran guru madrasah, jumlah peserta 30 orang; 3) Diklat peningkatan kompetensi multimedia guru madrasah, peserta 30 orang; 4) diklat metodologi pembelajaran bagi guru madrasah, peserta 30 orang; 5) diklat penilaian kinerja guru dan Pengembangan Keprofesionalan Berkelanjutan (PKB) guru madrasah, peserta 30 orang; 6) diklat penelitian tindakan kelas guru madrasah, peserta 30 orang; 
7) diklat instrumen penilaian guru madrasah, peserta 60 orang; 8) diklat mata pelajaran SKI, peserta 29 orang; 9) diklat mata pelajaran matematika guru MTs, peserta 27 orang; 10) Diklat mata pelajaran sosiologi guru Madrasah Aliyah, peserta 28 orang; 11) diklat mata pelajaran prakarya guru MTs, peserta 30 orang.

\section{Identitas Responden}

Berkenaan dengan responden yang menjadi sumber data dan informasi, terdiri dari guru agama maupun guru yang mengampu mata pelajaran umum yang selama ini bertugas sebagai pendidik madrasah di Kota Manado, baik Madrasah Ibtidaiah, Tsanawiyah, maupun Madrasah Aliyah yang telah mengikuti diklat mata pelajaran di Balai Diklat Keagamaan Manado, dengan interval waktu 2016-2017. Adapun deskripsi identitas responden, dikemukakan sebagai berikut:

\section{Karakteristik Berdasarkan Jenis Kelamin}

\begin{tabular}{|ll|l|l|l|l|}
\hline & & & & Valid & Cumulative \\
& & Frequency & Percent & Percent & Percent \\
\hline Valid & Perempuan & 60 & 74.1 & 74.1 & 74.1 \\
& laki-laki & 20 & 25.9 & 25.9 & 100.0 \\
& Total & 80 & 100.0 & 100.0 & \\
\hline
\end{tabular}

Berdasarkan tabel di atas, dapat dideskripsikan bahwa agregat 81 responden penelitian ini dapat diklasifikasikan; sebanyak 60 orang yang berjenis kelamin perempuan atau $74,1 \%$ dari jumlah responden dan ada sebanyak 21 orang yang berjenis kelamin laki-laki atau $21 \%$ dari jumlah responden, dengan demikian, dominan responden berjenis kelamin perempuan.

\section{Karakteristik Berdasarkan Masa Kerja}

\begin{tabular}{|ll|l|l|l|l|}
\hline & & & & $\begin{array}{l}\text { Valid } \\
\text { Plid }\end{array}$ & $\begin{array}{l}\text { Cumulative } \\
\text { Percent }\end{array}$ \\
\hline Valid & $<5$ tahun & 4 & 4.9 & 4.9 & 4.9 \\
& 5-20 tahun & 70 & 86.4 & 86.4 & 91.4 \\
& $>20$ tahun & 6 & 8.6 & 8.6 & 100.0 \\
& Total & 80 & 100.0 & 100.0 & \\
\hline
\end{tabular}

Berdasarkan tabel di atas dari 81 responden ada sebanyak 4 orang dengan masa kerja $<5$ tahun atau $4,9 \%$ dari jumlah responden,
70 orang dengan masa kerja 5-20 tahun atau $86,4 \%$ dari jumlah responden, dan 7 orang dengan masa kerja > 20 tahun atau 8,6\% dari jumlah responden. Berdasarkan Diagram batang dan lingkaran dapat kita lihat.

\begin{tabular}{|ll|l|l|l|l|}
\hline & & & & Valid & Cumulative \\
& & Frequency & Percent & Percent & Percent \\
\hline Valid & D3 & 1 & 1.2 & 1.2 & 1.2 \\
& S1 & 70 & 86.4 & 86.4 & 87.7 \\
& S2 & 9 & 12.3 & 12.3 & 100.0 \\
Total & 80 & 100.0 & 100.0 & \\
\hline
\end{tabular}

\section{Karakteristik Berdasarkan Pendidikan}

Berdasarkan tabel di atas dari 81 responden ada sebanyak 1 orang dengan pendidikan D3 atau 1,2\% dari jumlah responden, 70 orang dengan pendidikan $\mathrm{S} 1$ atau $86,4 \%$ dari jumlah responden, dan 10 orang dengan pendidikan S2 atau 12,3\% dari jumlah responden.

\section{Analisis Deskriptif Respons Guru terhadap Penyelenggaraan Diklat}

Dengan memanfaatkan instrumen riset; kuesioner dan didukung wawancara dengan kalangan responden yang terdiri dari guru, kepala madrasah, pengawas hasil analisis data ditemukan tingkat pengaruh diklat terhadap kinerja guru madrasah. Jika ditinjau dari respons guru dengan menggunakan pengukuran skala likert, terhadap dimensi materi diklat dengan tujuan indikator, rerata direspons dengan kategori baik (4.14); dimensi kualitas widyaiswara, rerata direspons dengan kategori baik (4.08); dimensi metode diklat, rerata direspons dengan kategori baik $(3,54)$.

Adapun tingkat respons terhadap variabel Y (kinerja guru), yang di-breakdown dari empat kompetensi: kompetensi tampak pada hasil analisis berikut: 1) kompetensi pedagogi; 2) kompetensi kepribadian; 3) kompetensi profesional, dan 4) kompetensi sosial. Keempat kompetensi tersebut kemudian di-breakdown ke dalam 14 indikator dengan respons rate masingmasing, sebagai berikut: 1) mengenal karakteristik peserta didik, rerata direspons dengan kategori baik (4.2); 2) menguasai teori belajar, rerata direspons dengan kategori baik 
(4.1); 3) menguasai pengembangan kurikulum dengan respons rerata dengan kategori baik $(4.0)$; 4) kegiatan pembelajaran dengan rerata respons terkategori baik (4.2);5) memahami dan mengembangkan potensi, dengan rerata respons terkategori baik (4.0); 6) komunikasi dengan peserta didik, rerata respons terkategori baik (4.2);

Indikator berikut adalah; 7) penilaian dan evaluasi terkategori baik (3.9); 8) bertindak sesuai dengan norma agama, hukum, sosial dan kebudayaan nasional Indonesia, rerata respons terkategori baik (4.2); 9) menunjukkan pribadi yang dewasa dan teladan, terkategori baik (4.2); 10) etos kerja, tanggung jawab yang tinggi, dan rasa bangga menjadi guru, rerata respons terkategori baik (4.1); 11) bersikap inklusif, bertindak obyektif, serta tidak diskriminatif, rerata respons terkategori sangat baik $(4.3) ; 12)$ komunikasi dengan sesama guru, tenaga pendidikan, orang tua peserta didik, dan masyarakat, rerata respons terkategori baik (4.1); 13) penguasaan materi struktur konsep dan pola pikir keilmuan mendukung mata pelajaran yang diampu, rerata respons terkategori baik (3.9), dan indikator 14) mengembangkan keprofesian melalui tindakan reflektif, dengan rerata respons terkategori baik (3.9).

\section{Asumsi Klasik \\ Uji Normalitas}

Uji yang digunakan untuk melihat normalitas nilai residual persamaan regresi yaitu uji kolmogorov smirnov. Sebelum melakukan pengujian yaitu terlebih dahulu menyusun sebuah hipotesis. Hipotesis dalam pengujian distribusi normal adalah sebagai berikut:

$$
\begin{aligned}
& \mathrm{H}_{0} \text { : data berdistribusi normal } \\
& \mathrm{H}_{1} \text { : data tidak berdistribusi normal }
\end{aligned}
$$

Kriteria pengujiannya bisa dengan membandingkan nilai kolmogorov-smirnov $\mathrm{Z}$ atau bisa dengan melihat nilai signifikannya yaitu Jika nilai sig(2-tailed) $\leq$ taraf signifikan $\alpha=0.05$ maka $\mathrm{H}_{0}$ ditolak atau $\mathrm{H}_{1}$ diterima begitu pun sebaliknya jika nilai sig (2-tailed) $\geq$ taraf signifikan $\alpha=0.05$ maka $\mathrm{H}_{0}$ diterima atau $\mathrm{H}_{1}$ ditolak. Berdasarkan hasil output SPSS diperoleh:
One-Sample Kolmogorov-Smirnov Test

a. Test distribution is Normal.

b. Calculated from data.

\begin{tabular}{|ll|l|}
\hline & & $\begin{array}{l}\text { Unstandardized } \\
\text { Residual }\end{array}$ \\
\hline $\mathrm{N}$ & & 80 \\
Normal Parameters & Mean & .0000000 \\
& Std. Deviation & 28.51789610 \\
Most Extreme Differences & Absolute & .109 \\
& Positive & .073 \\
& Negative & -109 \\
Kolmogorov-Smirnov Z & & .977 \\
Asymp. Sig. (2-tailed) & & .296 \\
\hline
\end{tabular}

Berdasarkan tabel di atas diperoleh nilai Asymp Sig. (2-tailed) =0,296 yang lebih besar dari taraf signifikan $\alpha=0,05=0.05{\text { maka } \mathrm{H}_{0}}$ diterima atau $\mathrm{H}_{1}$ ditolak, dalam hal ini maka data dianggap terdistribusi normal.

\section{Uji Multikolinearitas}

Berdasarkan hasil output uji multikolinearitas dengan menggunakan SPSS diperoleh tabel sebagai berikut:

\section{Tabel Uji Multikolinearitas}

Berdasarkan nilai tabel di atas diperoleh nilai VIF untuk semua variabel kurang dari 10 atau nilai tolerance lebih besar dari 0,01 sehingga dapat dikatakan bahwa setiap variabel independen saling bebas satu sama lain atau tidak terjadi korelasi satu sama lain sehingga dalam hal ini data bebas dari multikolinearitas.

\section{Uji Heteroskedastisitas}

Pengujian Heteroskedastisitas ini menggunakan metode grafik atau scatterplot yaitu dengan membuat plot error(residu) dengan predicted value. Kriteria pengujiannya: Jika terdapat pola tertentu seperti titik-titik yang membentuk suatu pola yang teratur (misalnya bentuk null plot, triangle, atau diamond) mengindikasikan terjadinya Heteroskedastisitas. Jika terdapat pola yang jelas atau titik-titiknya menyebar secara acak di atas maupun di bawah angka 0 pada sumbu $\mathrm{Y}$ maka tidak terjadi Heteroskedastisitas. 
Gambar 4.1. Diagram Uji Heteroskedastisitas

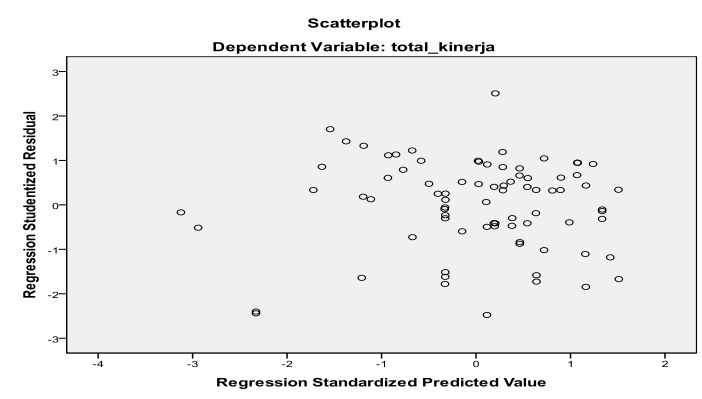

Berdasarkan hasil pengujian dengan menggunakan SPSS mengindikasikan bahwa pencaran data tidak menunjukkan suatu pola tertentu. Pencaran data menyebar secara acak, sehingga dapat disimpulkan bahwa data tidak mengalami heteroskedastisitas pada residual (sisa). Karena semua asumsi sudah terpenuhi maka dilakukan uji lanjut untuk melihat pengaruh dari variabel bebas (X1, X2 dan X3) secara bersamaan terhadap variabel terikat (Y).

\section{Analisis Pengaruh Diklat terhadap Kinerja Guru Madrasah}

Untuk melihat pengaruh diklat terhadap kinerja guru yaitu dengan menggunakan analisis regresi. Lebih tepatnya yaitu analisis regresi berganda dengan variabel independen atau bebas yaitu $X_{1}=$ metode pelatihan, $X_{2}=$ Materi diklat, dan $\mathrm{X}_{3}=$ pelatih diklat dan variabel terikat $Y$ yaitu total kinerja guru. Uji yang digunakan dalam analisis ini yaitu Uji tiap-tiap variabel $\mathrm{V}$ atau uji T. Uji ini digunakan untuk mengetahui pengaruh tiap-tiap variabel independen terhadap variabel dependennya. Sebelum melakukan pengujian yaitu terlebih dahulu menyusun hipotesis:

Hipotesis dalam uji ini sebagai berikut:

$\mathrm{H}_{0}$ : metode pelatihan $\left(\mathrm{X}_{1}\right)$, Materi diklat $\left(\mathrm{X}_{2}\right)$, dan pelatih diklat $\left(\mathrm{X}_{3}\right)$ tidak mempengaruhi kinerja guru (Y).

$\mathrm{H}_{1}$ : metode pelatihan $\left(\mathrm{X}_{1}\right)$, Materi diklat $\left(\mathrm{X}_{2}\right)$, dan pelatih diklat $\left(\mathrm{X}_{3}\right)$ mempengaruhi kinerja guru(Y).

Kriteria pengujiannya bisa dengan membandingkan nilai $\mathrm{T}$ hitung dan $\mathrm{T}$ tabel atau bisa dengan melihat nilai signifikannya yaitu Jika nilai sig. $\leq$ taraf signifikan $\alpha=0,05=0.05$ maka $\mathrm{H}_{0}$ ditolak atau $\mathrm{H}_{1}$ diterima begitu pun sebaliknya jika nilai sig. $\geq$ taraf signifikan $\alpha=$ $0,05=0.05$ maka $\mathrm{H}_{0}$ diterima atau $\mathrm{H}_{1}$ ditolak. Hasil uji $\mathrm{T}$ dengan menggunakan SPSS diperlihatkan. Maka, perlu dilakukan pemilihan model yang terbaik, dalam hal ini kita menggunakan metode stepwise.

Berdasarkan tabel di atas diperoleh model yang terbaik yaitu dengan membuang variabel bebas materi diklat dan pelatih diklat dan hanya menggunakan variabel bebas materi diklat sehingga model terbaik yang seharusnya digunakan yaitu pengaruh Materi diklat $\left(\mathrm{X}_{2}\right)$ terhadap kinerja guru (Y). Hipotesis dalam uji ini adalah sebagai berikut:

$\mathrm{H}_{0}$ : Materi diklat $\left(\mathrm{X}_{2}\right)$ tidak mempengaruhi kinerja guru $(\mathrm{Y})$.

$\mathrm{H}_{1}$ : Materi diklat $\left(\mathrm{X}_{2}\right)$ mempengaruhi kinerja guru (Y).

Berdasarkan hasil yang diperoleh di atas, dengan pertimbangan tidak mendapatkan model regresi yang baik ketika kita menggunakan analisis regresi berganda yang melibatkan 3 variabel independen. Kita menyarankan menggunakan analisis regresi sederhana dengan hanya melibatkan satu variabel independen dan satu variabel dependen yaitu menganalisis pengaruh masing-masing variabel bebas terhadap variabel terikatnya.

\section{Pengaruh Metode pelatihan $\left(X_{I}\right)$ terhadap kinerja guru (Y)} berikut:

Hipotesis dalam uji ini adalah sebagai

$\mathrm{H}_{0}$ : Metode pelatihan $\left(\mathrm{X}_{1}\right)$ tidak mempengaruhi kinerja guru (Y).

$\mathrm{H}_{1}$ : Metode pelatihan $\left(\mathrm{X}_{1}\right)$ mempengaruhi kinerja guru (Y).

Kriteria pengujiannya bisa dengan membandingkan nilai $\mathrm{F}$ hitung dan $\mathrm{F}$ tabel atau bisa dengan melihat nilai signifikannya yaitu Jika nilai sig. $\leq$ taraf signifikan $\alpha=0,05=0.05$ maka $\mathrm{H}_{0}$ ditolak atau $\mathrm{H}_{1}$ diterima begitu pun sebaliknya jika nilai sig. $\geq$ taraf signifikan $\alpha=$ $0,05=0.05$ maka $\mathrm{H}_{0}$ diterima atau $\mathrm{H}_{1}$ ditolak. 
Hasil uji F dengan SPSS diperlihatkan

\begin{tabular}{|l|l|l|l|l|l|}
\hline Model & Sum of Squares & Df & Mean Square & F & Sig. \\
\hline 1 Regression & 3314.198 & 1 & 3314.198 & 3.916 & $.051^{\mathrm{a}}$ \\
Residual & 66862.691 & 79 & 846.363 & & \\
Total & 70176.889 & 80 & & & \\
\hline
\end{tabular}

a. Predictors: (Constant), metode_pelatihan

b. Dependent Variable: total_kinerja

Hasil uji $\mathrm{F}$ menunjukkan nilai $\mathrm{F}$ hitung sebesar 3,916 dengan nilai signifikan sebesar 0,051 . Nilai sig. $=0.51 \geq$ taraf signifikan $\alpha=$ $0,05=0.05$ maka $\mathrm{H}_{0}$ ditolak atau $\mathrm{H}_{0}$ diterima yaitu metode pelatihan $\left(\mathrm{X}_{2}\right)$ mempengaruhi kinerja guru (Y). Untuk melihat seberapa besar sumbangsih yang diberikan untuk faktor lingkungan sekolah yaitu melihat model summary dari output SPSS sebagai berikut:

\section{Model Summary ${ }^{b}$}

a. Predictors: (Constant), metode_pelatihan

b. Dependent Variable: total_kinerja

\begin{tabular}{|c|l|l|l|l|}
\hline Model & & R Square & Adjusted R Square & $\begin{array}{l}\text { Std. Error of the } \\
\text { Estimate }\end{array}$ \\
\hline 1 & $.217 \mathrm{a}$ & 047 & .035 & 29.09232 \\
\hline
\end{tabular}

Berdasarkan tabel model summary nilai $\mathrm{R}$ menunjukkan nilai Pearson Correlation (korelasi pearson) yang menunjukkan seberapa kuat kadar hubungan antara kedua variabel. Dari tabel diperoleh nilai $\mathrm{R}=0,217$ yang masih tergolong korelasi lemah selanjutnya diperoleh pula nilai adjusted $\mathrm{R}^{2}$ adalah 0,35 atau $35 \%$ variasi kinerja guru dapat dijelaskan oleh faktor metode pelatihan. Sisanya dijelaskan oleh faktor-faktor lainnya selain metode pelatihan.

\section{Pengaruh Materi pelatihan $\left(X_{2}\right)$ terhadap kinerja guru (Y)}

Uji yang digunakan dalam analisis ini yaitu Uji serentak atau uji F. Uji ini digunakan untuk mengetahui pengaruh secara simultan atau bersama-sama semua variabel Independent terhadap variabel dependennya. Sebelum melakukan pengujian, hipotesis dalam uji ini adalah sebagai berikut:

$\mathrm{H}_{0}$ : Materi pelatihan $\left(\mathrm{X}_{2}\right)$ tidak mempengaruhi kinerja guru $(\mathrm{Y})$

$\mathrm{H}_{1}$ : Materi pelatihan $\left(\mathrm{X}_{2}\right)$ mempengaruhi kinerja guru $(\mathrm{Y})$
Hasil uji F dengan SPSS diperlihatkan:

\begin{tabular}{|l|l|l|l|l|l|}
\hline Model & Sum of Squares & Df & Mean Square & F & Sig. \\
\hline 1 Regression & 4871.285 & 1 & 4871.285 & 5.893 & $017^{\mathrm{a}}$ \\
Residual & 65305.604 & 79 & 826.653 & & \\
Total & 70176.889 & 80 & & & \\
\hline
\end{tabular}

a. Predictors: (Constant), materi_diklat

b. Dependent Variable: total_kinerja

Hasil uji $\mathrm{F}$ menunjukkan nilai $\mathrm{F}$ hitung sebesar 5,893 dengan nilai signifikan sebesar 0,017 . Nilai sig. $=0.017 \leq$ taraf signifikan $\alpha=$ $0,05=0.05$ maka $\mathrm{H}_{0}$ ditolak atau $\mathrm{H}_{1}$ diterima yaitu Materi pelatihan $\left(\mathrm{X}_{2}\right)$ mempengaruhi kinerja guru (Y). Untuk melihat seberapa besar sumbangsih yang diberikan untuk variabel materi pelatihan yaitu melihat model summary dari output SPSS sebagai berikut:

\section{Model Summary ${ }^{b}$}

\begin{tabular}{|l|l|c|c|c|}
\hline Model & $\mathrm{R}$ & $\mathrm{R}$ Square & Adjusted R Square & $\begin{array}{l}\text { Std. Error of the } \\
\text { Estimate }\end{array}$ \\
\hline $\begin{array}{l}\text { Di 1 } \\
\mathrm{m} \\
\text { en }\end{array}$ & $.263^{\mathrm{a}}$ & .069 & .058 & 28.75158 \\
\hline
\end{tabular}

a. Predictors: (Constant), materi_diklat

b. Dependent Variable: total_kinerja

Dari tabel diperoleh nilai $\mathrm{R}=0,263$ yang masih tergolong korelasi lemah selanjutnya diperoleh pula nilai adjusted $\mathrm{R}^{2}$ adalah 0,058 atau $5,8 \%$ kinerja guru dapat dijelaskan oleh variabel materi diklat. Sisanya yaitu sebesar $(100 \%-5,8 \%=94,2 \%)$ dijelaskan oleh faktorfaktor lainnya selain variabel materi diklat.

\section{Pengaruh pelatih diklat $\left(X_{3}\right)$ terhadap kinerja guru $(Y)$}

Uji yang digunakan dalam analisis ini yaitu Uji serentak atau uji F. Uji ini digunakan untuk mengetahui pengaruh secara simultan atau bersama-sama semua variabel independen terhadap variabel dependennya. Sebelum melakukan pengujian, hipotesis dalam uji ini adalah sebagai berikut:

$\mathrm{H}_{0}$ :Pelatih diklat $\left(\mathrm{X}_{3}\right)$ tidak mempengaruhi kinerja guru $(\mathrm{Y})$

$\mathrm{H}_{1}$ :Pelatih diklat $\left(\mathrm{X}_{3}\right)$ mempengaruhi kinerja guru (Y) 
Hasil uji F dengan SPSS diperlihatkan

\begin{tabular}{|l|l|l|l|l|l|}
\hline Model & Sum of Squares & Df & $\begin{array}{l}\text { Mean } \\
\text { Square }\end{array}$ & F & Sig. \\
\hline 1 Regression & 3963.077 & 1 & 3963.077 & 4.728 & $33^{\mathrm{a}}$ \\
Residual & 66213.812 & 79 & 838.150 & & \\
Total & 70176.889 & 80 & & & \\
\hline
\end{tabular}

a. Predictors: (Constant), pelatih_diklat

b. Dependent Variable: total_kinerja

Hasil uji $\mathrm{F}$ menunjukkan nilai $\mathrm{F}$ hitung sebesar 4,728 dengan nilai belum signifikan sebesar 0,033 . Nilai sig. $=0.33 \leq$ taraf signifikan $\alpha=0.05$ maka $\mathrm{H}_{0}$ ditolak atau $\mathrm{H}_{1}$ diterima, dengan demikian pelatih diklat $\left(\mathrm{X}_{3}\right)$ mempengaruhi kinerja guru (Y). Untuk melihat seberapa besar sumbangsih yang diberikan untuk variabel pelatih diklat yaitu melihat model summary dari output SPSS sebagai berikut:

\section{Model Summary ${ }^{b}$}

\begin{tabular}{|c|l|l|l|l|}
\hline Model & & R Square & $\begin{array}{l}\text { Adjusted } \\
\text { R Square }\end{array}$ & Std. Error of the Estimate \\
\hline 1 & $.238^{\mathrm{a}}$ & .056 & .45 & 28.95081 \\
\hline
\end{tabular}

a. Predictors: (Constant), widyaiswara

b. Dependent Variable: total_kinerja

Dari tabel diperoleh nilai $\mathrm{R}=0,238$ yang masih tergolong korelasi belum signifikan, selanjutnya diperoleh pula nilai adjusted $\mathrm{R}^{2}$ adalah 0,45 atau $45 \%$ variasi kinerja guru dapat dijelaskan oleh faktor pelatih diklat. Sisanya dijelaskan oleh faktor-faktor lainnya selain variabel pelatih diklat. Berdasarkan analisis pengaruh dari masing-masing variabel bebas terhadap variabel terikatnya, variasi yang diberikan untuk masing-masing variabel bebas $\mathrm{X}_{1}, \mathrm{X}_{2}$, dan $\mathrm{X}_{3}$ bisa dikatakan masih kurang signifikan.

Dengan memanfaatkan metode kombinasi yang dimaknai Creswell, sebagai pendekatan penelitian yang mengombinasikan atau mengasosiasikan bentuk kualitatif dan bentuk kuantitatif. Maka, pendekatan ini telah menghasilkan data numerik (statistical) berkenaan dengan pengaruh diklat yang telah dikemukakan di atas, yang intinya bahwa, pengaruh diklat belum signifikan dalam meningkatkan kinerja guru madrasah di Manado, masih ada faktor-faktor lainnya yang ditengarai ikut berpengaruh. Jika diasosiasikan dan atau dikombinasikan dengan data kualitatif, melalui hasil wawancara dan observasi dengan kalangan guru, pengawas, dan kepala madrasah, maka tampak beberapa komponen yang masih problematik dalam proses penyelenggaraan diklat mata pelajaran, terutama pada domain materi diklat, metode, dan kompetensi widyaiswara/instruktur.

Salah seorang informan (MN/52 Tahun) yang mengklaim telah delapan tahun menerima tunjangan profesi/sertifikasi, namun belum pernah mengikuti pelatihan untuk peningkatan kompetensi, sementara di sisi lain, terdapat juga beberapa orang guru yang justru secara berturutturut telah mengikuti diklat. Padahal, baginya, pendidikan dan pelatihan (in service training) merupakan keniscayaan dalam pengembangan kompetensi, profesionalisme, dan kinerja. Bahkan, salah seorang koleganya, mengklaim bahwa selama berprofesi sebagai guru, ia hanya sekali mengikuti diklat, itu pun katanya diklat prajabatan, sementara diklat teknis/fungsional masih menjadi "barang mewah" baginya.

Program ini sejatinya dilakukan secara terencana, terukur, dan juga berkelanjutan, sehingga persoalan pemerataan dan keadilan yang selama mengemuka di kalangan guru dapat diatasi. Hal ini selaras dengan adagium yang dikonstruksi E. Kim (2007),"The quality of education can not exceed the quality of teacher", tersirat bahwa mutu guru adalah conditio sine qua non (prasyarat utama) dalam membangun pendidikan yang unggul. Sebab, betapa pun berkualitasnya suatu kurikulum, sarana dan prasarana pendidikan yang lengkap, tetapi tidak memiliki guru yang berkualitas, termasuk melalui upaya peningkatan kapasitas berkelanjutan melalui diklat, maka semuanya akan bermuara akan absurditas; tidak ada jaminan siswa akan bermutu dan berprestasi.

Terkait dengan materi pembelajaran yang selama ini belum disentuh secara optimal para widyaiswara, menurut responden (AR/ 47 Tahun) adalah bahwa, diklat guru semestinya dibagi secara tepat, rasio antara teori 40 persen dan praktik 60 persen. Praktik mencakup membuat rencana pembelajaran sesuai dengan 
spesifikasi kelas, membuat alat peraga, merancang permainan mendidik, menganalisis kurikulum, dan mengajar di kelas dan laboratorium. Dari segi teori, mereka mesti memahami aspek profesional, pedagogi, dan silabus kurikulum. Tinggal memoles aspek praktik mendidik di sekolah/madrasah dan merancang sistem pembelajaran di kelas.

Terkait dengan materi maupun metode diklat, responden (MN/52) menilai bahwa para widyaiswara dan fasilitator masih lebih dominan memanfaatkan metode ceramah, dengan berorientasi pada tataran teoritis dan konseptual berkenaan dengan pembelajaran. Padahal, semestinya, diklat justru diarahkan secara langsung dan kongkret untuk memecahkan problem pembelajaran yang selama ini dihadapi guru di madrasah, misalnya proses penerapan pendekatan saintifik, penilaian, misalnya penilaian otentik yang meniscayakan penerapannya di madrasah seiring dengan implementasi Kurikulum 2013 misalnya.

Masing-masing diklat menurut informan (SR/ 51 Tahun), sejatinya guru diarahkan pada keterampilan mengembangkan sendiri silabus dan RPP yang tepat sesuai dengan kurikulum, dengan mengakomodasi kebutuhan di tingkat lokal. Termasuk teknik mendidik yang tidak selalu konvensional dan ketinggalan zaman. Guru sebaiknya diorientasikan untuk mulai bersikap kritis, dan secara simultan guru diarahkan dan dilatih agar dapat mendidik siswa dengan metode yang merangsang cara berpikir tingkat tinggi. Itu tidak bisa digapai dengan metode "jadul", seperti dikte dan hafalan. Melainkan, siswa harus paham konsep, lalu menganalisisnya sesuai usia atau jejang Pendidikan, dan mengekspresikan sambal memaparkan inti gagasan.

Intervensi dominan dalam pelatihan semestinya memastikan bahwa, peserta diklat memiliki pola berpikir kritis, peserta didorong untuk banyak membaca literatur, termasuk koran, majalah dan jurnal lalu mendiskusikannya di kelas terkait solusi dan cara meleburkannya dalam pendidikan seharihari. Dengan demikian, setiap mata ajar diarahkan pada kegiatan diskusi, analisis, dan praktik belajar mengajar. Selain memahami buku teks pelajaran, peserta juga didorong untuk memanfaatkan buku-buku perpustakaan dan mencari sumber-sumber terpercaya di internet.

Belajar, bagi responden, tidak bisa lagi terpaku pada kisi-kisi soal. Guru dituntut mengembangkan rasa ingin tahu (curiosity) siswa dan mengerahkan mereka mencari jawaban dengan cara kreatif sekaligus dapat mempertanggungjawabkan. Bradley dalam tulisannya,"Developing School: Making Inset Effective School," mengemukakan terkait pentingnya pelatihan bagi guru, sehingga mereka dapat mengajarkan hal-hal baru bagi para siswanya, dan sekolah mampu menghadapi setiap perubahan dengan penuh percaya diri. Sehingga, setelah melalui proses diklat, guru mampu meningkatkan efektivitas pembelajaran, menaikkan prestasi belajar siswa, dan menyebabkan guru memiliki keinginan yang lebih kuat untuk menerima berbagai inovasi baru.

Selain aspek pedagogi, yang juga tak kalah pentingnya adalah pengembangan karakter guru dalam diklat, sebab ternyata membentuk guru profesional tidak hanya pada keahlian mendidik, tetapi juga cara guru berpikir dan membawa diri di masyarakat. Selain mengasah otak, peserta diklat juga diarahkan untuk menjalani kehidupan yang penuh disiplin. Sikap serta perilaku mereka di asrama juga penting untuk dinilai secara seksama. Bahkan relasi antar teman sekamar, penilaian terkait kerapian, kebersihan, dan kedisiplinan. Jika ada guru yang tidak mampu bersosialisasi, dan bersikap abai itu berpengaruh pada penilaian selama mengikuti diklat. Itu semua perlu dipastikan demi menghasilkan guru bermutu dan berkarakter.

Problem yang masih menggelayuti proses penyelenggaraan diklat mata pelajaran sebagaimana dideskripsikan tadi, menurut beberapa informan tidak lepas dari belum optimalnya pemanfaatan Analisis Kebutuhan Diklat (AKD), di titik ini sebetulnya muara dari semua masalah tersebut. Sehingga, lanjut informan, jika domain AKD dibenahi, maka bisa dipastikan proses penyelenggaraan diklat akan berkualitas, sebagaimana yang menjadi ekspektasi kalangan stakeholders/users.

Tujuan analisis kebutuhan diklat diantaranya adalah untuk memastikan guru yang akan dipanggil mengikuti diklat betul-betul 
relevan dengan spesialisasinya, materi yang diajarkan selaras dengan kebutuhan riil guru di madrasah, dan memastikan metode yang akan digunakan sangat sesuai, serta memastikan widyaiswara yang akan mengampu materi diklat betul-betul sesuai dengan kompetensi dan atau rumpun spesialisasinya

\section{PENUTUP}

Mengacu pada analisis kuantitatif dan kualitatif di atas, maka dapat ditarik kesimpulan, bahwa ditinjau dari respons guru dengan menggunakan pengukuran Skala Likert, terhadap dimensi materi diklat dengan tujuan indikator, rerata direspons dengan kategori baik, dimensi kualitas widyaiswara, rerata direspons dengan kategori baik, dimensi metode diklat, rerata direspons dengan kategori baik. Adapun tingkat respons terhadap variabel $\mathrm{Y}$ (kinerja guru), yang di-breakdown dari empat kompetensi dengan masing-masing indikatornya, sebagai berikut: 1) kompetensi pedagogi; 2) kompetensi kepribadian; 3) kompetensi profesional, dan 4) kompetensi sosial, yang rerata direspons dengan kategori baik.

Adapun pengaruh diklat secara parsial terdapat pengaruh, meskipun belum terlalu signifikan, hal ini menunjukkah hubungan yang positif variabel materi, metode diklat, dan kompetensi widyaiswara/fasilitator, hal ini mengindikasikan, jika ketiga variabel tersebut ditingkatkan atau dioptimalkan, maka variabel Y (kinerja guru) akan ikut mengalami peningkatan. Hasil uji $\mathrm{F}$ menunjukkan nilai $\mathrm{F}$ hitung sebesar 3,916 dengan nilai signifikan sebesar 0,051 . Nilai sig. $=0.51 \geq$ taraf signifikan $\alpha=$ $0,05=0.05$ maka $\mathrm{H}_{0}$ ditolak atau $\mathrm{H}_{0}$ diterima yaitu metode pelatihan $\left(\mathrm{X}_{2}\right)$ mempengaruhi kinerja guru $(\mathrm{Y})$, demikian pula hasil uji $\mathrm{F}$ menunjukkan nilai $\mathrm{F}$ hitung sebesar 4,728 dengan nilai belum signifikan sebesar 0,033. Nilai sig. $=0.33 \leq$ taraf signifikan $\alpha=0.05$ maka $\mathrm{H}_{0}$ ditolak atau $\mathrm{H}_{1}$ diterima, dengan demikian pelatih diklat $\left(\mathrm{X}_{3}\right)$ mempengaruhi kinerja guru (Y). Hasil ini juga menandakan bahwa masih terdapat variabel yang ditengarai akan ikut berkontribusi terhadap kinerja guru, yang justru tidak masuk dalam penelitian ini, sehingga direkomendasikan agar dilakukan penelitian lanjutan untuk memperkuat hasil penelitian ini.

Analisis kualitatif menunjukkan bahwa, masih terdapat problem yang menggelayuti penyelenggaraan diklat yang meniscayakan pembenahan, sehingga penyelenggaraan diklat lebih berkualitas ke depan, salah satunya yang paling urgen adalah optimalisasi perumusan dan sekaligus komitmen untuk memanfaatkan hasil Analisis Kebutuhan Diklat (ADK), untuk memastikan guru yang akan dipanggil mengikuti diklat betul-betul relevan dengan spesialisasinya, materi yang diajarkan selaras dengan kebutuhan riil guru di madrasah, dan memastikan metode yang akan digunakan sangat sesuai, serta memastikan widyaiswara yang akan mengampu materi diklat betul-betul sesuai dengan kompetensi dan atau rumpun spesialisasinya.

\section{UCAPAN TERIMA KASIH}

Artikel yang ada di hadapan pembaca, tak lepas dari sumbangsih beberapa pihak, yang sejatinya mendapatkan apresiasi. Dengan demikian, penulis mengaturkan banyak terima kasih pada Kepala Balai Diklat Keagamaan Manado, widyaiswara, guru-guru madrasah yang menjadi sumber data dan informasi penelitian yang kemudian diekstrak menjadi artikel ini. Apresiasi yang sama juga penulis sampaikan pada editor dan mitra bestari AlQalam yang menyunting artikel ini, sehingga dinyatakan layak menjadi bagian dari Jurnal AlQalam volume 25, Nomor 2 Tahun 2018.

\section{DAFTAR PUSTAKA}

Creswell, John W. , 2010, Research Design: Qualitative, Quantitative, and Mixed Methods Approach, diterj. Achmad Fawaid: Research Design: Pendekatan Kualitatif, Kuantitatif, dan Mixed, Yogyakarta: Pustaka Pelajar

Daymon, Christine, et.al. 2008. Qualitative Research Methods in Public Relations and Marketing Communication, diterj. Cahya Wiratama: Metode-Metode Riset Kualitatif dalam Public Relation, Yogyakarta: Bentang Pustaka 
Furqon, 2009. Statistik Terapan untuk Penelitian, Bandung: Alfabeta

Kusumastuti, Penny, 2014. Membumikan Transparansi dan Akuntabilitas Kinerja Sektor Publik: Tantangan Berdemokrasi Ke depan, Jakarta: PT Grasindo.

Merriam, Sharran, B. et. al, 2016. Qualitative Research: A Guide to Design and Implementations, San Francisco: Jowsey Bass

Moeheriono, 2012. Perencanaan, Aplikasi, dan Pengembangan Indikator Kinerja Utama Bisnis dan Publik, Jakarta: Rajawali Pers.

Musfah, Jejen, 2015. Manajemen Pendidikan: Teori, Kebijakan, dan Praktik, Jakarta: Prenadamedia.

Peraturan Pemerintah Nomor 101 Tahun 2000, tentang Pendidikan dan Pelatihan jabatan Pegawai Negeri Sipil
Peraturan Menteri Agama Nomor 43 tahun 2016 tentang Sistem Informasi Manajemen Pendidikan dan Pelatihan pada Kementerian Agama,

Permendiknas Nomor 16 tahun 2006 tentang Kualifikasi Akademik Guru

Sevilla, Consuelo, et.al, 1993. An Introduction to Research Methods, diterj. Alimuddin Tuwu: Pengantar Metode Penelitian, Jakarta: UI-Press.

Undang-Undang Nomor 20 Tahun 2003 tentang Sistem Pendidikan Nasional,

Wirawan, 2009. Evaluasi Kinerja Sumber Daya Manusia: Teori, Aplikasi, dan Penelitian, Jakarta: Salemba Empat 